\author{
Оливье Азам \\ Выстая Нормальная школа / Институт лингвистики при Сорбонне \\ (Париж, Франичия) \\ azamoam@club-internet.fr
}

\title{
ОСОБЕННОСТИ ВЫБОРА ВИДА ИНФИНИТИВА, УПОТРЕБЛЯЕМОГО В СОВРЕМЕННОМ РУССКОМ ЯЗЫКЕ В ФУНКЦИИ ДРЕВНЕРУССКОГО СУПИНА
}

На фоне обычного преобладания совершенного вида инфинитива для выражения цели - особенно после союза «чтобы» - обращает на себя внимание противоположная тенденция, когда инфинитив цели употребляется без союза как дополнение к глаголу передвижения, то есть в функции древнерусского супина. Здесь наблюдается явная склонность к употреблению несовершенного вида, особенно заметная, когда при введении в высказывание союза «чтобы» несовершенный вид инфинитива приходится заменять на совершенный вид.

Наполеон не просто шёл в Россию, он шёл освобождать крестьян от крепостного права. [М. Задорнов]

₹ Наполеон не просто шёл в Россию, он шёл, чтобы освободить крестьян от крепостного права.

Представляется, что изучение закономерностей выбора вида инфинитива цели вынуждает выделить среди инфинитивов цели особую подкатегорию инфинитивасупина, требующую отдельного изучения.

После рассмотрения того, как осуществляется выбор вида инфинитива после разных приставочных и простых глаголов передвижения, будет показано, что бо́льшая совместимость инфинитива с несовершенным видом объясняется как особой, тесной связью между глаголом передвижения с инфинитивом в супинальном употреблении, так и особым типом цели, который выражает этот инфинитив. В отличие от остальных инфинитивов цели, современный инфинитив в функции древнерусского супина выражает цель лишь вторично, через выражение места назначения, превращая назначение в цель перемещения.

Ключевые слова: выбор вида в инфинитиве, глаголы движения, цель, супин, супинальное употребление инфинитива, аллатив. 


\section{0. Введение. Инфинитив назначения как наследник древнерусского супина}

Настоящая работа посвящена одной из каверзнейших трудностей в освоении русского языка - выбору вида инфинитива «цели», или «назначения» при глаголе передвижения.

При выражении цели действия внимание говорящего сосредоточивается на достижении результата, который часто совпадает с достижением предела, выражающимся употреблением совершенного вида (CB), что и объясняет преимущественное использование инфинитивов СВ для выражения цели.

В самом распространённом типе выражения обстоятельства цели посредством глагола, а именно в придаточных предложениях с союзом чтобы, пропорция случаев употребления СВ так велика, что в педагогических целях иностранным студентам обычно говорят, - правда, не без обобщений и упрощений, — что после чтобы без отрицания по умолчанию употребляется СВ:

1. Наполеон не просто шёл в Россию, он шёл, чтобы освободить крестьян от крепостного права.

А употребление несовершенного вида (НСВ) инфинитива после чтобы требуется лишь при наличии таких веских факторов, как повтор действия или фокусирование на его обстоятельствах и на самом его процессе ${ }^{1}$.

Зато при употреблении инфинитива цели в качестве дополнения к глаголу передвижения тенденция противоположна: преобладает употребление инфинитива HCB.

2. Наполеон не просто шёл в Россию, он шёл освобождать крестьян от крепостного права. [М. Задорнов]

В классическом учебнике О.П. Рассудовой отмечено, что «в сочетаниях, передающих направленность субъекта к действию, преимущественно употребляется инфинитив несовершенного вида» [Рассудова 1968: 63]. К сожалению, Рассудова уделяет данному вопросу лишь пару страниц, и большинство её примеров не аутентичны, а выдуманы $a d$ hoc, при этом проведённое ею разграничение между «сочетаниями, имеющими значение цели», и «сочетаниями, обозначающими не цель, а лишь направленность субъекта к какому-то действию», не помогает разобраться в этом вопросе в силу своей недостаточной ясности. Тем не менее предлагаемое разграничение дало интересную зацепку и послужило отправной точкой для нашего размышления.

Как известно, в функции обстоятельства цели после глагола передвижения современный инфинитив заменяет древнерусский с у п и н , другую глагольную форму именного типа. Ср. в церковнославянском переводе Синайского патерика Х в. (по: [Пожгаи 2003]):

${ }^{1}$ В этой работе будет рассматриваться только инфинитив без отрицания, выражающий неповторяющееся действие. 
3. $\quad$ Идоущю на ръкоу воды питъ. Синайский Патерик $69 \mathrm{v} .17$

4. $\quad$ Идоу видњ ть тебе. Синайский Патерик 46v.15

5. $\quad$ Идохъ мытъ с^. Синайский Патерик 133.10

Супин существовал не только в общеславянском, но и в других индоевропейских языках (например, в латыни), но с самого появления старославянского и древнерусского как письменных языков с супином стал конкурировать инфинитив. В следующем знаменитом отрывке «Повести временных лет» встречается супин княжитъ, соединённый с инфинитивом володъти при помощи союза $u$ :

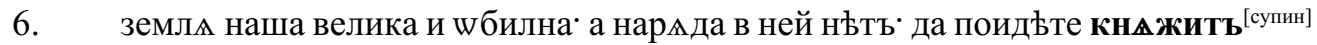

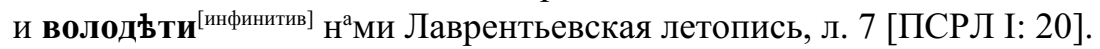

Судя по работам И. Пожгаи и Г.А. Молькова, эта форма, по всей видимости, дольше сохранялась в живой восточнославянской речи, чем в южнославянской ${ }^{2}$. Дата окончательной потери супина в истории русского языка достаточно поздняя. «В древнерусских рукописях < ..> употребление супина наблюдается вплоть до XIV века, и только начиная с XV века он был вытеснен окончательно инфинитивом» [Пожгаи 2003: 400].

Мы попробуем объяснить преобладание употребления НСВ инфинитива при глаголах передвижения. Разумеется, супин как таковой давно ушёл в прошлое. Но, учитывая, что современный инфинитив цели при глаголе передвижения выполняет не одну из исконных функций инфинитива, а заменяет древнюю глагольную форму, расшатанную давно, но утраченную сравнительно недавно, можно задаться вопросом, не связано ли преобладание употребления НСВ изучаемого инфинитива с его ролью бывшего супина?

Опираясь на тщательный анализ взаимоотношений глагола передвижения и инфинитива, мы покажем, чем сочетание «глагол передвижения + инфинитив» существенно отличается от параллельной конструкции с союзом чтобы с инфинитивом, и выявим необходимость признать особенный статус инфинитива, употребляемого в современном русском языке в функции древнего супина.

Сначала мы рассмотрим выбор вида инфинитива в зависимости от типа и формы управляющего глагола передвижения, начиная как раз с тех глаголов передвижения, которые требуют инфинитива СВ.

2 «При учете материала рукописей разных изводов отчётливо выделяются две группы: восточнославянские, сохраняющие супин почти в том же объёме, в каком он был известен старославянским памятникам, и южнославянские (болгарского и сербского изводов), в которых отражена систематическая правка -тъ на -ти.» [Мольков 2003: 328]. 


\section{1. Пределы выбора вида инфинитива назначения}

\section{1. Практически обязательное употребление совершенного вида при некоторых приставочных глаголах передвижения}

Примеры от №7 до №28 показывают, после каких глаголов - вопреки общей тенденции - практически всегда или в большинстве случаев требуется инфинитив назначения CB. Речь идёт о парных приставочных глаголах передвижения с приставкой за- (типа заходить/зайти) $)^{3}$ :

7. Он зашёл купить папирос. [А.Н. Толстой. Черная пятница (1924) НКРЯ]

8. Зайду спросить, как у него дела. [Интернет]

9. Отец его ждет сегодня с обеда, вероятно, не утерпит и зайдет рассказать окончание «казуса». [Н.Э. Гейнце. Аракчеев (1898) НКРЯ]

10. Он сказал, что завтра поутру зайдет узнать о моем здоровье. [Н. Г. Чернышевский. Что делать? (1863) НКРЯ] ${ }^{4}$

${ }^{3}$ На первый взгляд выбор вида инфинитива после зайти в следующем примере является исключением из правила, требующего инфинитива назначения СВ после зайти:

Мы сидели еще с барышнями у Арины Семеновны в ожидании отца Николая, который присылал из церкви с покорнейшею просьбою подождать его, приказывая, что, как он освободится, так сам зайдет просить достопочтенных гостей. [А. Ф. Писемский. Плотничья артель (1855)]

На самом деле этот гапакс объясняется особым значением глагола просить в данном контексте. В этом предложении просить значит 'пригласить', а в этом значении инфинитив просить употребляется в литературе XIX века в качестве инфинитива как СB, так и НСВ. Поэтому в вышеприведённом примере Писемского представляется целесообразным интерпретировать просить после зайдет как инфинитив СВ.

Мы выражаем благодарность И.Б. Иткину, который указал нам несколько примеров, содержащих инфинитив просить в смысле пригласить, явно употребляемый как инфинитив СВ. Из «Плотничьей артели» Писемского И.Б. Иткин приводит два примера:

— Позвольте, батюшка Алексей Феофилактыч, — начала она, — просить вас осчастливить меня вашим посещением.

- Нимфодора Михайловна, Минодора Михайловна, позвольте и вас просить к себе на чашку чаю.

Но самый убедительный пример употребления инфинитива просить как инфинитива совершенного вида И.Б. Иткин нашёл в «Горе от ума» А.С. Грибоедова (1824):

С л у га. Полковник Скалозуб. Прикажете принять?

Фамусо в (встаёт). Ослы! сто раз вам повторять? Принять его, позвать, просить, сказать, что дома, что очень рад. Пошёл же, торопись.

Из этих примеров можно однозначно заключить, что у классиков форма инфинитива просить в смысле 'пригласить' - двувидовая или что глагол просить функционировал как «полуторавидовой», по выражению И.Б. Иткина.

${ }^{4}$ Но с другим глаголом передвижения в синонимичном контексте употребляется инфинитив HCB:

Забеспокоившись, он быстро оделся и пошел узнавать у соседей: не видел ли кто-нибудь его матери и старухи в круглых очках? [А.И. Пантелеев. Ленька Пантелеев (19381952) НКРЯ] 
11. Что это на тебя нашло? - Заходил попросить о помощи. Дурацкая история, но я не знаю, как из нее выпутаться. [Игорь Ефимов. Суд да дело (2001) НКРЯ]

12. Правда, когда бывал за границей, заходил посмотреть соборы большие, знаменитые. [Владимир Молчанов, Консуэло Сегура. И дольше века... (1999-2003) НКРЯ] (В этом примере действие «заходить» повторяется, и при каждом повторе происходит осмотр соборов.)

об одновидовых глаголах передвижения СВ с приставкой $c$ - (типа $c x o d u m b)^{5}$ :

13. Наш сосед дядя Гриша сходил посмотреть на этот памятник и вернулся недовольный. [Дина Рубина. На солнечной стороне улицы (1980-2006) НКРЯ]

14. Сходил снять копии с последних страниц - вот этих самых. [Геннадий Николаев. Вещие сны тихого психа // «Звезда», 2002 НКРЯ]

15. Он сходил напоить коня, затем спустился к Ангаре, чтобы посмотреть, не видать ли чего постороннего. [Валентин Распутин. Живи и помни (1974) НКРЯ]

16. - Я схожу позвонить по телефону-автомату, - сказал Щуровский. [Л. Овалов (Л. С. Шаповалов). Рассказы майора Пронина (1939) НКРЯ]

17. Вот и Опанас не сходил посмотреть, что делают ослы [Н. В. Кукольник. Максим Созонтович Березовский (1844) НКРЯ]

18. Я сходил поздравить ее и был приглашен на вечер. [А.Н. Вульф. Дневник (1828) НКРЯ]

о приставочных глаголах передвижения СВ с приставкой в- (типа войти):

19. Никто не вошел проверить, спят ли они на самом деле. [Мариам Петросян. Дом, в котором... (2009) НКРЯ]

20. Вошёл взглянуть, проверить. <Rassudova 1968>

о парных приставочных глаголах передвижения с приставкой вы- (типа вblxoдить/ выйтu); при этих глаголах в качестве инфинитива назначения в СВ употребляется, как правило, делимитативный глагол на по-:

21. Он Вышел на минуту подышать свежим воздухом. [Спагис 1968: 313]

22. Итак, дождаться, когда он выйдет покурить или подышать перед сном океанской прохладой, и сделать это. [Дина Рубина. Белая голубка Кордовы (2008-2009) НКРЯ]

23. Инструктор периодически выходит покурить, оставляя меня одну за рулем. [Дарья Данилова. Вождение за нос (2014) НКРЯ]

${ }^{5}$ Разумеется, после сходить также регулярно встречается инфинитив назначения НСВ. Но только тогда, когда речь идёт о другом глаголе cходить: не об одновидовом сходить СВ, а о НСВ парного глагола сходить/сойти в смысле 'спускаться/спуститься':

Чудились ему смутные лики святых, куда зачастую сам Спаситель сходил утешать измученного и избитого мальчика. [В.И. Немирович-Данченко. Святые горы (1880) НКРЯ]

В отличие от pefectivum tantum сходить, пара cxoдить/сойти не входит в список исключений глаголов передвижения, требующих инфинитива назначения СВ. 
24. Старому доктору было скучно постоянно находиться в своей комнате, иногда он выходил посидеть на крыльце [В. А. Каверин. Открытая книга (19491956) НКРЯ]

о приставочных глаголах передвижения СВ с приставкой под- (типа подойти):

25. Подошёл узнать, спросить, посмотреть. [Рассудова 1968: 66]

26. Я хотела подойти рассмотреть черно-белые фотографии на стенах. [Елена Негода. Педсовет с последним из могикан (2003) НКРЯ]

27. К вождю же сейчас даже подойти положить цветочки нельзя. [Первомайские глюки // «Богатей» (Саратов), (2003) НКРЯ]

28. К К нему как бы невзначай могли подойти рассказать о себе, о своей жизненной ситуации, узнать его мнение. [Геннадий Пруцков. И помыслы были чисты (2003) НКРЯ]

При глаголе же НСВ подходить возможно употребление как инфинитива СВ, так и инфинитива НСВ:

\section{«Подходить» + инфинитив СВ}

29. Тур Хейердал подходит поздравить меня. [Павел Павел. «Оживление» истуканов // «Техника - молодежи» // «Техника — молодежи», 1989 НКРЯ]

30. Он неловок, не подходит приветствовать [двувидовой], поиеловать как раньше. [В. В. Бибихин. Сергей Сергеевич Аверинцев (1984-1986) НКРЯ]

31. Винсент начинает учиться в мастерской Кремона, но за исключением Тулуз-Лотрека никто не подходит посмотреть, что у него получается. [Север Гансовский. Винсент Ван Гог (1970) НКРЯ]

32. Нынче няня подходит взять его от меня, он засмеялся, зажмурился и прижался ко мне - верно, думал, что спрятался. [Л.Н. Толстой. Война и мир. (1867-1869) НКРЯ]

\section{«Подходить» + инфинитив НСВ}

33. А в конце службы, когда крест все подходят целовать, он еще и каждого лично обольет! [Евгения Пищикова. Пятиэтажная Россия (2007) НКРЯ]

34. Начинаются танцы. Мнимый француз-Дубровский подходит приглашать Машу. [Д. Марголин. Спутник меломана. (1908) НКРЯ]

35. Чуть дрожа, он встал, и так же крадучись подошёл к портрету вплоть, как подходят просить благословения. [С.Н. Сергеев-Ценский. Печаль полей (1909) НКРЯ]

36. Дети высыпают из залы и подходят благодарить дедушку. [М.Е. Салтыков-Щедрин. Пошехонская старина. (1887-1889) НКРЯ]

\section{2. Объяснение выбора инфинитива СВ при вышеперечисленных глаголах}

a) При глаголах типа заходить/зайти или при одновидовом сходить употребление СВ инфинитива объясняется спецификой семантики приставки: в приставках 
за- и $c$ - в одновидовых глаголах передвижения заложена идея о возвращении, о передвижении туда и обратно. Конечная цель передвижения - возвращение к исходной точке, отсюда и употребление инфинитива СВ для завершения действия.

У глаголов типа войти или подойти, помимо семантики предлога, на выбор вида инфинитива могло влиять воздействие близких по смыслу конструкций, требующих CB.

\section{б) войти}

С приставочными глаголами на в- в настоящем времени с о верш ен н ого вида предпочтение отдаётся другой конструкции - типа войду, сделаю, в которой инфинитив заменяется на настоящее время сов ершенного вида. Вместо конструкции прошедшего времени Bom я вошёл спросить: «Hy, как дела?» скажут в будущем:

37. Вот я войду, спрошу: «Ну, как дела?» [Интернет]

Не исключено, что у глаголов с приставкой в- систематическое употребление настоящего времени СВ оказало влияние на выбор вида инфинитива и в прошедшем времени.

\section{в) подойти}

Когда сам глагол подойти употребляется в инфинитиве, исключительное употребление СВ инфинитива глагола назначения объясняется тем, что оборот «подойти + инфинитив» восходит не к употреблению инфинитива в качестве супина, а к другой грамматической структуре, в которой инфинитив не управляется глаголом подойти, а стоит наравне с ним и употребляется в совершенном виде. Первоначальная структура ещё видна в высказываниях, в которых подойти отделяется от второго инфинитива запятой [38-40] или соединяется с ним при помощи союза [41]. В таких высказываниях второй инфинитив в совершенном виде просто развивает смысл инфинитива подойти, уточняя, какое действие вызвало перемещение в пространстве.

\section{Инфинитив, отделённый от подойти запятой}

38. «Наверное, боятся летать, - решила она. - Надо подойти, успокоить». Подошла, склонилась к старшему, хотела сказать что-нибудь доброе. [Кровавый промысел // «Солдат удачи» (2004) НКРЯ]

39. Так и хочется подойти, погладить ее и сказать: «Гут!» [Владимир Скрипкин. Тинга // «Октябрь» (2002) НКРЯ]

40. Еще вчера можно было подойти, спросить что-то, а сегодня человека уже нет, и ничего не спросишь!» [Александр Терехов. Бабаев (2003) НКРЯ]

\section{Инфинитив, соединённый с подойти союзом $u$}

41. Мне остается только хотя бы подойти к ней и попросить прощения, а дальше... [Переписка в ісq (2008) НКРЯ]

Структура первоначальной конструкции ещё явственнее при наличии нескольких инфинитивов, уточняющих причину перемещения: 
42. К дедушке всегда можно подойти, обнять и погладить пальчиком между глаз и по носу, и десятибалльный шторм моментально сменится полным штилем. [Татьяна Соломатина. Большая собака (2009) НКРЯ]

43. Сейчас подойти, обнять , взять на руки теплое, сладкое тельце. [А.А. Андронова. Золотая рыбка (2008) НКРЯ]

г) Что же касается глаголов типа выйти, в наших примерах (от №21 до №24) при них употребляется инфинитив СВ дел и м и тат и в ны Х глаголов с приставкой по-. Выбор СВ обусловлен здесь синергией семантики приставки глагола передвижения $b b l-$ и приставки делимитативного инфинитива $n o^{-6}$.

\section{2. Преобладание инфинитива НСВ, когда выбор совершается свободно (но не произвольно)}

\section{1. Глагол принадлежит к грамматической категории «глаголов передвижения»}

Со всеми остальными глаголами передвижения возможно употребление обоих видов при явном преобладании инфинитива НСВ. Эту тенденцию иллюстрируют примеры употребления НСВ при самых показательных глаголах передвижения - при простом однонаправленном идти (примеры №№ 44-68) и ингрессивном СВ пойти (примеры от №№ $71-82$ ).

идти

- Глагол передвижения в настоящем времени несовершенного вида

44. Лично я иду спать. [Екатерина Завершнева. Высотка (2012) НКРЯ]

45. Не зря же в русском языке принято говорить «иду слушать оперу», а не «иду смотреть оперу». [И.К. Архипова. Музыка жизни (1996) НКРЯ]

46. Ладно, иду зубрить, дело привычное. [Там же]

47. Эта мысль мне нравится, отвечает Митя, но в постель потом - сейчас я иду спасать кошку, а вы, девушки, будете мне ассистировать. [Екатерина Завершнева. Высотка (2012) НКРЯ]

48. Иду успокаивать Сашу. [Татьяна Тарасова, Виталий Мелик-Карамов. Красавица и чудовище (1984-2001)]

49. Ещё мы с Русланом во вторник идем записываться в горный клуб наш мгушный (если хочешь, присоединяйся) [Переписка в ісq (2008) НКРЯ]

${ }^{6}$ О решающей роли делимитативной приставки в синергии, ведущей к выбору СВ, свидетельствует тот факт, что после выходить/выйти употребление НСВ не исключается. Иными словами, после выходить/выйти чаще всего употребляется либо инфинитив СВ делимитативного глагола, либо инфинитив НСВ:

Соколов вышел провожать гостей [Василий Гроссман. Жизнь и судьба (1960) НКРЯ]

Вдруг Гольцман поднимется и выйдет искать? [Александр Терехов. Каменный мост (1997-2008) НКРЯ] 
50. Я, как обычно, в 6.30 иду сына будить, а он уже не спит, настроение - хуже некуда [Наши дети: Подростки (2004) НКРЯ]

51. Я Яду мыть руки в ванную. [Зоя Масленикова. Разговоры с Пастернаком (2001)]

52. Бабуля будит меня в пять часов утра, я иду доить корову и выгоняю в стадо - какие утра, боже мой! [Татьяна Набатникова. День рождения кошки (2001)]

\section{- Глагол передвижения в прочедием времени}

53. Вечерком, когда все шли спать, я написал письмо своему хозяину. [Л.Н. Толстой. Отрочество (1854) НКРЯ]

54. (О Наполеоне) Он не просто шёл в Россию, он шёл освобождать крестьян от крепостного права. [Михаил Задорнов. На концерте (2014)]

55. Павел шел истреблять христиан, и вдруг перед ним предстал Сам Христос [Митрополит Антоний (Блум). Учение Павла не от людей, а от Бога (19751985) НКРЯ]

56. Она покидала свой черёд дел, шла помогать соседке [Александр Солженицын. Матренин двор (1960) НКРЯ]

57. А после приобретения нужных ему изданий шёл осматривать экспонаты краеведческого музея. [Илья Петрусенко. Я вдыхаю ветер воли... (2003) НКРЯ]

58. Она знала о нём всё, - его чтение детских книг в постели перед сном, его лицо, когда он шёл чистить зубы... [Василий Гроссман. Жизнь и судьба (1960)]

\section{- Глагол передвижения в инфинитиве}

59. Все собираются идти смотреть удивительного фокусника. [М. Ю. Лермонтов. Герой нашего времени (1839-1841)]

60. - Марта сказала, что ты ещё с вечера сговаривался с садовником идти ловить птиц около оранжереи. [Ю.О. Домбровский. Обезьяна приходит за своим черепом (1943-1958) НКРЯ]

61. Мне надо идти собирать рюкзак. [Переписка в ісq (2008)]

62. Но Алексей, прождав её напрасно, мог идти отыскивать в селе дочь Василья кузнеца. [А. С. Пушкин. Барышня-крестьянка (1830) НКРЯ]

\section{- Глагол передвижения в повелительном наклонении}

63. То ли дорогу иди строить, то ли мастерскую заводи. [А. И. Мусатов. Клава Назарова (1958) НКРЯ]

64. «Ничего не бойся, иди опять учиться, справишься». [Кундузой Юлдашева. Дочери смотрят на нас (1987) НКРЯ]

65. Я немедленно Маринке говорю: - Сейчас же иди выгуливать собаку. [Сергей Есин. Стоящая в дверях (1992) НКРЯ]

66. Закончил школу, получил документ - иди сдавать самостоятельно. [Сергей Шерстенников. Генерал Федоров: спасибо за подсказку (2002) НКРЯ] 


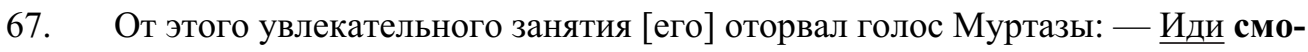
треть, про вас показывают. На маленьком экране переносного телевизора... [Евгений Чижов. Перевод с подстрочника (2012) НКРЯ]

68. - Ты иди смотреть закат, - говорит она. [Нина Щербак. Роман с филфаком (2010) НКРЯ]

Преобладание НСВ инфинитива назначения при однонаправленном глаголе особенно заметно после глагола передвижения в повелительном наклонении, когда наблюдается конкуренция между «иди + инфинитив в НСВ» и близкой по смыслу конструкцией «иди + императив», в которой глагол в императиве стоит в $\mathbf{C B}$, а не в НСB:

69. - - Ты иди встреть ее внизу, - сказали Ваньке. [Василий Шукшин. Ванька Тепляшин (1972-1973) НКРЯ]

70. 는 чисть картошку и протирай столы. [Татьяна Соломатина. Акушер-ХА! Байки (2009) НКРЯ]

\section{пойти}

\section{- Глагол передвижения в настоящем времени совершенного вида}

71. Я от вас не скрою, что пойду говорить по телефону с княгиней Верой Николаевной. [А.И. Куприн. Гранатовый браслет (1911) НКРЯ]

72. А когда распущенное чадо принесёт аттестат в конце года, я пойду нюхать и колоться? [Наши дети: Подростки (2004) НКРЯ]

73. ППйдёшь гулять, а очутишься всегда здесь у ворот. [А.Н. Островский. Гроза (1860) НКРЯ]

74. Гагин объявил нам, что пойдёт сегодня рисовать этюд с натуры! [И. С. Тургенев. Ася (1858) НКРЯ]

75. Дело моё важное, вероятно, сам прокурор пойдёт обвинять. [А. Ф. Кони. Игуменья Митрофания. Из записок и воспоминаний судебного деятеля (1908) НКРЯ]

\section{- Глагол передвижения в повелительном наклонении}

76. П Пойдёмте пиво пить. [А.Н. Толстой. Черная пятница (1924) НКРЯ]

77. Тугилово от нас недалеко, всего три версты: подите гулять в ту сторону или поезжайте верхом; вы, верно, встретите его. [А.С. Пушкин. Барышня-крестьянка (1830) НКРЯ]

78. Едут, в самом деле. Пойдём встречать. Узнает ли она меня? [А.П. Чехов. Вишневый сад (1904) НКРЯ]

\section{- Глагол передвижения в инфинитиве}

79. Пришлось пойти гулять одной. [Сати Спивакова. Не всё (2002) НКРЯ]

\section{- Глагол передвижения в прошедшем времени}

Сохраняя свое главное значение перемещения в другое место, глагол пошёл фокусирует внимание именно на начале действия, обозначаемого инфинитивом 
назначения, выступая по отношению к нему в роли почти ингрессивного фазисного глагола:

80. - Тут он отвернулся, чтоб скрыть своё волнение, пошёл ходить по двору около своей повозки. [М. Ю. Лермонтов. Герой нашего времени (18391841) НКРЯ]

81. И пошёл переодеваться, мыться, облил голову холодной водой, смочил одеколоном и причесал короткие курчавые волосы, ещё раз взглянул в зеркало: лицо было свежо, глаза блестели! [И. Бунин. Митина любовь. (1924)]

82. После обеда Анна пошла одеваться в свою комнату, и Долли пошла за ней. [Л.Н. Толстой. Анна Каренина (1878)]

С глаголом идти примеры с инфинитивом СВ встречаются редко и, преимущественно, в прошедшем времени:

83. Я не себя шёл показать, мне журнал дорог. [Г. Я. Бакланов. Жизнь, подаренная дважды (1999) НКРЯ]

84. И он шёл проверить, лично удостовериться. Но - инкогнито. [Там же]

85. Леонидов сам выслушал от него сегодня обидные слова и, однако, шёл: может, даже как раз и шёл доказать, что его зря, напрасно обидели. [Константин Симонов. Живые и мертвые (1955-1959) НКРЯ]

При глаголе идти, стоящем в презенсе, примеры употребления инфинитива крайне редки:

86. Он говорит, что < ..> наши жилища должны принадлежать его воинам и что он цёт отобрать все это у тебя, у нас. [Л. А. Чарская. Галина правда (1912)]

С глаголом пойти в настоящем и прошедшем временах инфинитив СВ встречается ещё реже, и почти все примеры восходят к XIX в. или даже к концу XVIII в. ${ }^{7}$

87. Теперь пойду сделать к тому распоряжение. [Д.И. Фонвизин. Недоросль (1782)]

88. Напоивши их, пошла одеться. Няня мне сказала: «Не сказывайте вашему мужу, что вы были ночью у них». [А. Е. Лабзина. Воспоминания (1810) НКРЯ]

89. - Папа, и я пойду с вами, - сказала, картавя, княжна. (...) - Allons! сказал князь и, пока княжна пошла одеться, провел гостя в кабинет, который тоже оказался умно и богато убранным кабинетом [А.Ф. Писемский. Тысяча душ (1858) НКРЯ]

Зато после инфинитива «пойти» довольно часто встречается инфинитив СВ:

7 Зато в близкой по смыслу конструкции типа пойду сделаю инфинитив назначения НСВ заменяется настоящим временем СВ:

Я пойду скажу, чтобы вам что-нибудь приготовили да чтобы накормили вашего кучера на кухне. [Михаил Шишкин. Всех ожидает одна ночь (1993-2003) НКРЯ] 
90. - Да... - неохотно отозвалась Надежда Михайловна, вставая, чтобы пойти nомыть липкие от апельсина руки [Марина Зосимкина. Ты проснешься. (2015) НКРЯ]

91. Ну, что ж, пойти поработать?.. [Юрий Трифонов. Предварительные итоги (1970) НКРЯ]

92. Могу ли я спросить ваше благородие, - спросил отрок, - должен ли я дожидаться его величества здесь или пойти доложить? [Ю.Н. Тынянов. Малолетный Витушишников (1933) НКРЯ]

93. Только не засни опять, пожалуйста, мне ещё надо пойти разбудить твою маму. [Г.А. Газданов. Вечер у Клэр / Начало романа (1930) НКРЯ]

Это отклонение от общей тенденции к употреблению инфинитива НСВ при простых однонаправленных глаголах, скорее всего, объясняется влиянием близкой по смыслу конструкции, в которой инфинитив пойти не управляет вторым инфинитивом, а соединяется с ним при помощи союза $u$. В последнем случае оба инфинитива стоят на одном плане, и, разумеется, второй может стоять в $\mathrm{CB}^{8}$ :

94. Когда барышня говорит: «Настроение неважное, надо пойти и накупить себе всякой Ла Перлы», имеется в виду накупить себе не только женственного белья тонкой работы оной марки, но и прочей изящной всячины, которая по весне так повышает девичий тонус. [Невинный допинг // «Домовой» (2002) НКРЯ]

\section{2. Глагол, управляющий инфинитивом, обозначает передвижение в широком смысле и не принадлежит к категории глаголов движения}

Как супин в древнерусском, инфинитив назначения в НСВ употребляется также при глаголах, не принадлежащих к грамматической категории глаголов передвижения. Примеров значительно меньше, но здесь тоже преобладает инфинитив НСВ - не только при глаголах, обозначающих непредельное действие (98), но и при предельных глаголах, которые достигнут своего предела (99).

95. Первый появившийся офицер <..> послал будить командира роты [Олег Павлов. Степная книга (1990-1998) НКРЯ]

96. Ты и меня послал умирать, но я вот, уж извини, выжил... [Николай Дежнев. Год бродячей собаки (2002) НКРЯ]

97. Бельё сушить повесили. (Из к/ф [Русские сериалы])

98. - Потом сел играть в карты, а я пошла одеваться; в этот вечер он был в нашей ложе и на другой день объявлен женихом. [И. А. Гончаров. Обрыв (1869) НКРЯ]

99. В эту пасхальную ночь 1914 года, после замечательной ночной службы в церкви Екатерининского дворца, мы все вчетвером, без отца, который был с Царской Семьей в Ливадии, отправились разговляться домой. [Боткина 2010: 195]

${ }^{8}$ См. выше употребление инфинитива СВ при инфинитиве подойти (1.2.в, примеры №38 до №40). 


\section{3. Эллиптические обороты. Употребление инфинитива-супина, как правило в НСВ, возможсно даже при эллипсисе глагола передвижения}

В русском языке часто опускается сам глагол передвижения, если в высказывании есть указание на место назначения: «T

Эл ли п ти че с ки е высказывания с опущением глагола передвижения являются, вероятно, самыми показательными примерами преобладания выбора НСВ для выражения инфинитива назначения:

100. Бери и делай. [Комментарий] И куда? Стены красить? [Интернет, ВКонтакте]

101. - - Тренер, Вы куда?

- Знакомиться. (Из к/ф [Русские сериалы])

102. (После минуты молчания водитель говорит случайной попутчице, которая только что упомянула жениха). А вы? С родителями знакомиться? (Из к/ф [Русские сериалы])

Подобные примеры эллиптических высказываний доказывают, что инфинитив при глаголе передвижения обозначает в пе рв ую о чередь именно назначе н и е , а не цель, что и отражается на выборе НCB. A contrario наличие инфинитива НCВ позволяет адресанту правильно интерпретировать эллипсис и понять, что был опущен именно глагол передвижения.

\section{3. Типология инфинитивов назначения НСВ при глаголе передвижения}

Обилие примеров позволяет составить типологию инфинитивов, употребляемых в несовершенном виде.

\section{1. Инфинитив обозначает непредельное действие или предельное действие, представляемое как непредельное}

- Инфинитив НСВ может обозначать непредельное действие или действие, представляемое как непредельное:

103. Иду спать.

\# Мне нехорошо. Пойду прилягу.

104. Пойдёмте ужинать. И снова настала тишина. [Б. Л. Пастернак. Воздушные пути (1924) НКРЯ]

105. Пойду готовить. (Из к/ф [Русские сериалы])

106. Ладно! Я бухать поехал. Если что, пишите в ЛС. [Интернет]

Здесь глагол передвижения - это почти что фазисный глагол, указывающий на начало действия. Это касается в особенности глагола пойти в прошедшем времени:

107. Стиль: пошла поливать огород. [Виктория Складчикова. Интернет] 
108. Х Хватит дуться! Пошли танцевать! (Из к/ф [Русские сериалы])

109. Пойдёмте танцевать... (Танцует с Петей.) [А.П. Чехов. Вишневый сад (1904) НКРЯ]

\section{2. Инфинитив обозначает предельное действие}

- Инфинитивом может обозначаться также предельное действие, и здесь следует различать несколько случаев.

\subsection{1. Инфинитив обозначает предельное действие, которое можно себе} представить как сложный продолжительный процесс

\subsubsection{1. Первый вариант}

Действие, обозначаемое инфинитивом, не обязательно достигнет своего предела.

110. О чём может мечтать провинциальная девчонка, приехавшая покорять Москву? (Из к/ф [Русские сериалы])

111. Ладно, пойду мириться ${ }^{[и к 3]}$. (Из к/ф [Русские сериалы])

\# Пошла... Пойду помирюсь с ним и выйду за него. (В. Даль. Старик годовик. 1832)

\# Я пойду помирюсь с ней. (Из к/ф [Русские сериалы])

Здесь употребление НСВ не вызывает никаких вопросов, так как о достижении предела речь не идёт.

\subsubsection{2. Второй вариант}

Действие, обозначаемое инфинитивом, скорее всего, достигнет своего предела, но говорящий по каким-то причинам воспринимает его как оказывающее некоторое «сопротивление» либо потому, что действие неприятно говорящему, либо потому, что оно кажется ему более или менее сложным:

112. - В Москву?

- Да, поеду сдаваться. Из к/ф [Русские сериалы]

113. А Вы туда случайно не няней наниматься пришли? Из к/ф [Русские сериалы]

114. Иди оформлять пропуск. Из к/ф [Русские сериалы]

115. Потом сел играть в карты, а я пошла одеваться; в этот вечер он был в нашей ложе и на другой день объявлен женихом. [И. А. Гончаров. Обрыв (1869)]

3.2.2. Инфинитив обозначает простое предельное действие, долженствующее достигнуть своего предела и не представляющее особой сложности

\section{- Совершенный вид}

Разумеется, такие действия могут быть выражены посредством инфинитива СВ. Употребление инфинитива СВ особенно часто встречается при глаголах 
выйти и прийти в прошедшем времени. Здесь можно привести, между прочим, три примера из Рассудовой:

116. Он вышел на дорогу посмотреть, идёт ли Люба. [Рассудова 1968: 65]

117. Я приехал к тебе погостить. [Спагис 1968: 313]

118. Я вообще-то попрощзаться пришла. Я уезжаю. (Из к/ф [Русские сериалы])

119. Пришёл проститься. [Рассудова 1968: 64]

120. ㅍнёл дать Вам совет, как организовать работу. [Там же: 65]

\section{- Несовершенный вид}

Но видовая особенность инфинитива назначения при глаголе передвижения заключается в том, что даже если он обозначает простое предельное д ей с т в и е, инфинитив может употребляться в НСВ.

121. В два часа ночи встаю, иду снимать кастрюлю с огня. [Татьяна Тарасова, Виталий Мелик-Карамов. Красавица и чудовище (1984-2001) НКРЯ]

122. Тут мне кто-то звонит, пошел отвечать, но в трубке было молчание, затем смех и какой-то шум. (Из к/ф [Русские сериалы])

123. ППйдём знакомиться с пассажиром. (Из к/ф [Русские сериалы])

Вместо того чтобы представить предельное действие как точку или ограниченный отрезок времени, говорящий, выбирая НСВ инфинитива, имеет возможность представить его как п о л у п р я м у ю, наподобие непредельного или сложного предельного действия.

\section{3. Определение круга глаголов, которые невозможнно употреблять в инфинитиве несовершенного вида при глаголе передвижения для обозначения простого предельного действия, долэенствующего достигнуть своего предела}

Примеры (124)-(134) показывают, что приемлемость употребления инфинитива НСВ для обозначения действия, долженствующего достигнуть своего предела, прямо зависит от степени сложности, которую говорящий может приписать действию, обозначаемому инфинитивом назначения. Чем проще действие, обозначаемое инфинитивом, тем меньше вероятность употребления НСВ вида.

124. Виталий побежал после уроков домой оставить сумку.

125. Виталий побежал после уроков домой, чтобы оставить сумку.

126. *Виталий пюбежал поеле уроков домой оетавлять еумку.

127. *Виталий побежал поеле уроков домой, чтобы оетавлять сумку.

128. *Ноеле урөкөв Виталий будет өетавлять еумку дома.

129. Анна пошла в библиотеку взять новый учебник.

130. Анна пошла в библиотеку, чтобы взять новый учебник.

131. *Анна пошла в библиотеку брать новый учебник.

132. Анна пошла в библиотеку выбрать новую книгу. 
133. ?? Анна пошла в библиотеку выбирать новую книгу.

134. Анна пошла в книжный магазин выбирать новую книгу.

Мы установили, что в НСВ, как правило, не употребляются лишь инфинитивы тех глаголов, которые в том же самом контексте не могут употребляться в будущем времени НСВ в общефактическом значении (см. №128).

Вычеркнутые примеры могут быть корректны (даже в случае действия, которое должно достигнуть предела), но только при особых обстоятельствах. Можно сказать: Пошла брать новый учебник, но это значит, что брать - это целая процедура. Поэтому можно сказать также Пошла выбирать - но это опять акцент на длительности, т. е. действие не такое простое. Обычно, когда вы идете в библиотеку за книгой, вы знаете, какую книгу взять. Но если вы заходите в книжный магазин, процесс может быть сложнее: вы необязательно знаете, какую книгу купите и купите ли вообще. Поэтому употребление НСВ в варианте № 134 безоговорочно принимается информантами, а без широкого контекста — как в примере № 133 вызывает у них сомнения.

\section{4. Выводы \\ 4.1. Выражение цели через назначение. Первичность аллативного значения инфинитива, употребляемого в современном языке в функции древнерусского супина}

Из рассмотрения приведённых примеров можно заключить, что преобладание употребления НСВ инфинитива при глаголе передвижения объясняется а лла т и в н ы м значением, присущим инфинитиву, употребляемому в роли древнерусского супина.

Нельзя согласиться с О.П. Рассудовой, что инфинитив-супин «обозначает не цель». Разумеется, инфинитив в своем супинальном употреблении существует в блоке с управляющим глаголом и выступает здесь как естественный распр остран и тель глагола передвижения. Инфинитив действительно обозначает в первую очередь назначен ие, но это не повод не видеть в нём также выражение цели. На самом деле инфинитив-супин всегда обозначает и направление, и цель, но цель он выражает только вторично, через выражение назначения. В других же инфинитивах цели первично именно обозначение цели, а ал лати вн а я сема, как правило, отсутствует. Аллативная сема отсутствует или совсем уходит на задний план даже после глаголов передвижения, употребляемых с союзом чтобы, так как при помощи союза синтаксически чётко отделяется назначе н и е от ц ел и, на которой в этом случае и сосредотчивается внимание говорящего, ориентируя его чаще всего на выбор СВ с союзом чтобы. Но в инфинитиве-супине первично именно аллат и в о е значение, а выражение цели только в ы тека ет из самого аллативного значения. 
Первоначальное аллативное значение инфинитива-супина чётче всего ощущается, когда инфинитив употребляется как дополнение к бесприставочному однонаправленному глаголу: Иду сnать. Инфинитив-супин сnать приводит необходимое уточнение места назначения.

\section{2. Древнерусский супин. \\ Диахроническое подтверждение первичности аллативного значения современного инфинитива при глаголе передвижения}

Первичность аллативного значения вытекает из истории этого инфинитива. Что такое общеславянский супин, который был заменён изучаемым нами инфинитивом? Именная форма, от которой сохранилась лишь устойчивая форма винительного падежа, употребляемого в качестве аллатива, то есть для обозначения места направления.

Итак, этимологически любой супин древнерусского языка и, следовательно, семантически любой инфинитив направления, заменивший супин, является не только обстоятельством цели, но и - в первую очередь - обстоятельством ме ста с а л л а т и в ны м значением. Вот почему современный инфинитив в супинальном употреблении выражает заодно направленность и цель, но в первую очередь - направленность, и только во вторую очередь цель, делая из самого действия, обозначающего направленность, цель передвижения.

Ввиду первичности выражения направленности и неотделимости инфинитивасупина от глагола передвижения, все семы, которые так или иначе уточняют описываемое передвижение, играют значительную роль, которая отражается на выборе вида.

Вырисовывается такая картина: при союзе чтобы по умолчанию употребляется $\mathrm{CB}$, а при употреблении инфинитива-супина по умолчанию выбирается НCB. Как мы напомнили во введении, с союзом чтобы для замены СВ инфинитива на НСВ вид требуются веские причины. При употреблении же инфинитива-супина наблюдается аналогичная, хотя и противоположная ситуация: по умолчанию употребляется инфинитив $\mathrm{HCB}$, и несовершенный вид заменяется совершенным только при наличии таких факторов, как семантика приставки глагола передвижения (зайти, выйти) или инфинитива (покурить, подыпать), вес контекста (пойти купить чего-нибудь на ужин), лексическое значение глагола в инфинитиве или влияние близких по смыслу, но синтаксически разных конструкций (войду, скажу; пойду спрошу; можно подойти, обнять и погладить, и т. д.).

При этом, когда употребляется несовершенный вид с союзом чтобы, конструкция с союзом почти приравняется к конструкции с инфинитивом без союза и, наоборот, при употреблении инфинитива с о в е рш е н н о го вида после глагола передвижения без союза чтобы конструкция с инфинитивом-супином по смыслу и типу фокусирования почти приравняется к конструкции с союзом чтобы. 


\section{5. Заключение. Пояснительные схемы. Инфинитив цели как точка, отрезок времени или полупрямая. Полупрямая как типичное представление об инфинитиве-супине}

Рассмотрим логическую цепочку А-В-С, в которой «А» обозначает глагол передвижения, «В»- действие в инфинитиве, и «С» - результат действия в инфинитиве или действия, следующие за действием «В».

Когда говорящий выбирает конструкцию «чтобы + инфинитив», он смотрит на конец этой цепочки, на связь между В и С, лексически выражаемую союзом чтобы и эксплицитно выделяемую употреблением СВ:

Наполеон не просто шёл в Россию, он шёл, чтобы освободить крестьян от крепостного права.

Инфинитив после чтобы выражает только цель, чаще всего конечную цель. Поэтому при помощи союза чтобы редко делается акцент на самом процессе.

Зато, когда вместо чтобы выбирается конструкция с инфинитивом назначения и цели, употребляемым как древний супин,

Наполеон не просто шёл в Россию, он шёл освобождать крестьян от крепостного права.

говорящий больше фокусируется на связи между А (то есть передвижением) и В (действием в инфинитиве), чем между В (действием в инфинитиве) и С (результатом действия в инфинитиве или действиями, следующими за действием в инфинитиве).

С пр агм ати че с ко й точки зрения в первом случае, с союзом чтобы, говорящий смотрит вперёд, направо. Во втором же случае - при употреблении инфинитива в функции супина - он смотрит левее. Впрочем, видимо, этот прагматический нюанс именной формы глагола, выражающей заодно направление и цель перемещения, уже чувствовался латинскими грамматиками. Supinus на латыни значит 'загнутый назад'. В этом-то и раскрывается парадоксальный статус инфинитива-супина: хотя он обозначает направление и цель передвижения, он выражает их, прежде всего, как распространение передвижения и сосредоточивает внимание говорящего именно на связи между действием-назначением и исходным пере д в и же е и е м , чаще всего оставляя на периферии поля зрения результат действия в инфинитиве. Именно этим и объясняется, что в примере Рассудовой:

135. Звонок. Тата бежит открывать. [Рассудова 1968: 64] инфинитив-супин позволяет представить предельное, несложное действие, неминуемо долженствующее достичь своего результата, именно как п р о ц е с , тогда как инфинитив цели после чтобы требовал бы здесь выбора СВ. В предложении «Звонок. Тата бежит открывать» для говорящего важна связь между действиями «бежать» и «открывать», а не то, кого Тата увидит, открыв дверь, или то, что произойдёт потом.

Итак, употребляя инфинитив в качестве супина, говорящий может представить себе цепочку действий тремя разными способами. Вернёмся в заключение к трём показательным примерам О.П. Рассудовой [1968: 65], изменяя предлагаемые ею схемы. 
1. Действие-объект (инфинитив) представляется как точка.

1)

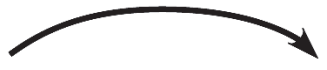

Отец пошёл на дорогу

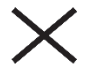

nосмотреть, не идёт ли Люба.

2. Действие-объект представляется как отрезок времени, контекстуально ограниченный, в первую очередь, последовательными действиями.

2)

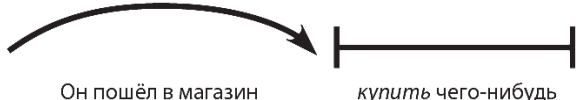

на ужин.

В обоих случаях употребляется $\mathrm{CB}$, даже при таком глаголе, как пошёл. Для инфинитива-супина эти первые две схемы иллюстрируют исключение, сближая его с конструкцией с союзом чтобы.

Пра в и ло иллюстрирует третья схема:

3)

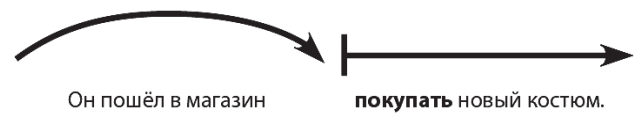

При употреблении инфинитива-супина вместо конструкции с союзом чтобы говорящий обычно представляет действие как полупрямую: Иду сnать. Он пошел покупать новый костюм. В поле зрения говорящего входит только начальный этап действия-объекта, говорящий фокусируется на стыке между движением и действием-объектом (иду и спать, пошёл и покупать, бежит и открывать), а достижение предела действия в инфинитиве остается вне фокусирования, чем и объясняется употребление НСВ не только с непредельными глаголами (иду спать, иди работать), как ожидалось, но и с предельными глаголами (пошла переодеваться, Тата бежит открывать, иду снимать кастрюлю с огня), что для иностранца может на первый взгляд оказаться особенно парадоксальным на фоне общего преобладания СВ для выражения цели.

Поэтому для изучения микрограмматики выбора вида при выражении цели инфинитивом нам представляется необходимым чётко отделить инфинитивы, выражающие только цель, не от инфинитивов, выражающих «лишь направленность субъекта к какому-то действию», как предлагала О.П. Рассудова, а от инфинитивов, выражающих цель только в тор и н о и через выражение наз на чен и я. Для последних предлагаем название «инфинитив-супин» в значении «инфинитива, употребляемого в современном русском языке в функции древнерусского супина». Такое название полностью соответствует как современному употреблению, так и истории этих форм, из которой они получили свои видовые особенности.

\section{Источники}

Боткина 2010 - T. Е. Боткина. Воспоминания о Царской семье // Царский лейбмедик. СПб., 2010. С. 51-439.

НКРЯ - Национальный корпус русского языка 
ПСРЛ I - Полное собрание русских летописей. Т. І. Лаврентьевская летопись. M., 1997.

Русские сериалы - Сообщество «Русские сериалы, фильмы, мелодрамы» в социальной сети «ВКонтакте», 2010-2019 гг. (https://vk.com/videos-57851 085)

\section{Литература}

Бондарко А.В. Вид и время русского глагола (значение и употребление). М., 1971.

Виноградов В.В. Русский язык. Грамматическое учение о слове. М.; Л., 1947 / Под ред. Г. А. Золотовой. 4-е изд. М., 2001.

Маслов Ю. С. Вид и лексическое значение глагола в современном русском литературном языке // Известия Академии наук СССР. Отделение литературы и языка. Т. 7. Вып. 4. 1948. С. 303-316.

Мольков Г. Супин в древнерусских списках Евангелия XI-XIII веков // Rozprawy komisji językowej. Tom LVI. 2018. C. 319-332.

Мирохина Т.М. Грамматическая категория вида русского глагола: учебное пособие. Елец, 2009.

Падучева E.B. Семантика вида и точка отсчета (в поисках инварианта видового значения) // Известия АН СССР. Сер. «Литература и язык». Т. 45. 1986. № 5. C. 413-424.

Падучева E. B. К семантике несовершенного вида в русском языке: общефактическое и акциальное значение // Вопросы языкознания. 1991. № 6. С. 34-45.

Падучева E. В. Результативные значения несовершенного вида в русском языке: общефактическое и акциональное // Вопросы языкознания. 1993. № 1. С. 64-74.

Падучева E. B. Семантические исследования: Семантика времени и вида в русском языке, семантика нарратива. М., 1996.

Пожгаи И. Употребление супина в Синайском патерике // Studia Slavica Savariensia. 2003. 1-2. С. 397-403.

Пожгаи И. Употребление инфинитива в Синайском патерике // Studia Slavica Hungarica. 2013. 58/2. С. 449-458.

Рассудова О.П. Употребление видов глагола в современном русском языке. М., 1968.

Cпагис A. A. Парные и непарные глаголы в русском языке. М., 1968. 
Olivier AZAM

École Normale Supérieure, Centre de Linguistique en Sorbonne

(Paris, France)

azamoam@club-internet.fr

\section{PARTICULARITIES OF THE CHOICE OF ASPECT FOR MODERN RUSSIAN INFINITIVES USED WITH THE FUNCTION OF THE OLD RUSSIAN SUPINE}

It is a well-known fact that infinitives of purpose are mostly used in the perfective, in particular after the conjunction ctoby. But when we examine the choice of the aspect of infinitives of purpose coming immediately after a verb of motion (without a conjunction), we notice the completely opposite tendency of using mostly the imperfective. This use of the imperfective aspect becomes especially noticeable after the conjunction ctoby + clause when the imperfective aspect must be replaced by the perfective.

Napoleon ne prosto šël v Rossiju, on šël osvoboždat' krest'jan ot krepostnogo prava.. [M. Zadornov]

= Napoleon ne prosto šël v Rossiju, on šël, čtoby osvobodit' krest'jan ot krepostnogo prava.

It appears that the study of patterns in the choice of aspect of the infinitive of purpose obliges us to distinguish among infinitives of purpose a special subcategory of infinitives used in Modern Russian in the syntactic function of the Old Russian supine. This subcategory requires dedicated research.

After briefly reviewing the choice of the aspect of the infinitive after different prefixed and simple verbs of motion, we demonstrate that the greater compatibility of the infinitive following a verb of motion with the imperfective could be explained by a special close connection between the verb of motion and the infinitive used as the former supine, as well as by a special type of purpose expressed by the infinitive after a verb of motion. Unlike other infinitives of purpose, the modern infinitive used in the function of the Old Russian supine expresses purpose secondarily, through the expression of destination. The infinitive is thus used in an allative meaning so that destination comes first, and purpose is only a consequence of the expression of destination.

Keywords: choice of aspect in the infinitive, verbs of motion, purpose, supine, infinitive of purpose, allative.

\section{References}

Bondarko A.V. Vid i vremya russkogo glagola (znachenie i upotreblenie). Moscow, 1971.

Maslov Yu. S. Vid i leksicheskoe znachenie glagola v sovremennom russkom literaturnom yazyke. Izvestiya Akademii nauk USSR. Otdelenie literatury i yazyka. T. 7. Vyp. 4. 1948. S. 303-316. 
Mirokhina T. M. Grammaticheskaya kategoriya vida russkogo glagola: uchebnoe posobie. Elets, 2009.

Mol'kov G. Supin v drevnerusskikh spiskakh Evangeliya XI-XIII vekov. Rozprawy komisji językowej. Tom LVI. 2018. Łódź: Łódzkie towarzystwo naukowe. S. 319-332.

Paducheva E. V. K semantike nesovershennogo vida v russkom yazyke: obshchefakticheskoe i aktsial'noe znachenie. Voprosy yazykoznaniya. 1991. № 6. S. 34-45.

Paducheva E. V. Rezul'tativnye znacheniya nesovershennogo vida v russkom yazyke: obshchefakticheskoe i aktsional'noe. Voprosy yazykoznaniya. 1993. № 1. C. 64-74.

Paducheva E. V. Semanticheskie issledovaniya: Semantika vremeni i vida v russkom yazyke, semantika narrativa. Moscow, 1996.

Paducheva E. V. Semantika vida i tochka otscheta (v poiskakh invarianta vidovogo znacheniya). Izvestiya Akademii nauk SSSR. Ser. «Literatura i yazyk». T. 45. 1986. № 5. C. 413-424.

Pozhgai I. Upotreblenie infinitiva v Sinayskom paterike. Studia Slavica Hungarica. 2013. 58/2. C. 449-458.

Pozhgai I. Upotreblenie supina v Sinayskom paterike. Studia Slavica Savariensia. 2003. 1-2. C. 397-403.

Rassudova O.P. Upotreblenie vidov glagola v sovremennom russkom yazyke. Moscow, 1968.

Spagis A. A. Parnye i neparnye glagoly v russkom yazyke. Moscow, 1968.

Vinogradov V. V. Russkiy yazyk. Grammaticheskoe uchenie o slove. Moscow; Leningrad, 1947 / Pod red. G. A. Zolotovoy. 4-e izd. Moscow, 2001. 